\title{
The food web in the pelagic environment
}

\author{
Ramón Margalef \\ Instituto de Investigaciones Pesqueras, Barcelona, Spain
}

\begin{abstract}
KURZFASSUNG: Das Nahrungsnetz in der pelagischen Umwelt. Vergleichende Studien über die Organisation des Nahrungsnetzes während verschiedener Stadien von Planktonsukzessionen können Aufschlüsse liefern über Gesetzmäßigkeiten der Energietransformation. Von dieser Annahme ausgehend, werden zunächst verschiedene Stadien von Phytoplanktonsukzessionen beschrieben und dann an Hand von Beispielen aus der Literatur und theoretischen Erwägungen allgemeinere Gesetzmäßigkeiten abgeleitet. Phytoplanktonpopulationen verändern sich im Verlaufe von Sukzessionen in ganz bestimmter Weise: Die Durchschnittgröße der Zellen und die relative Häufigkeit von Organismen mit Eigenbewegung nehmen zu, während Produktivität oder Zellteilungsrate abnehmen; ferner kommt es zu Veränderungen in der chemischen Zusammensetzung, etwa zu einer Abnahme der Menge an Chlorophyll. Im Verlauf der Sukzessionen verändert sich das Nahrungsangebot für die Zooplankter; dieser Umstand führt zu Verschiebungen in der Komposition der Zooplanktonpopulationen. Die Geschwindigkeit, mit welcher Phytoplanktonsukzessionen fortschreiten, ist ein sehr wichtiger Faktor; "grazing" ist hier möglicherweise als Geschwindigkeitsregulativ wirksam. Ganz allgemein wird im Verlauf gewöhnlicher Sukzessionen Nahrung, welche in Form von kleinen dispers suspendierten Partikeln in einem mehr oder minder turbulenten Wasserkörper vorliegt, ersetzt durch geringere Nahrungsmengen, welche in größeren Partikeln konzentriert sind und in einer stärker organisierten (stratifizierten) Umwelt vorkommen. In den ersten Sukzessionsstadien sind unspezifische Filtrierer im Vorteil; in späteren Stadien werden jedoch räuberische Formen und solche, die sich auf immer größere Nahrungsorganismen konzentrieren, bevorzugt. In den späteren Sukzessionsstadien ist die Gesamtmenge der transferierten Energie möglicherweise geringer, aber der Nutzeffekt scheint größer zu sein.
\end{abstract}

\section{INTRODUCTION}

Symposia are held for the benefit of discussion. It seems appropriate therefore to profit from the present opportunity by discussing problems not yet properly understood and possible new ways to gain insight into the forces that shape the patterns of energy transfer in the pelagic ecosystem, rather than by presenting a review of existing information; in fact, there already exists an excellent one on copepods by ANRAKU (1963).

Experimental study is basic, although difficult, and often yields divergent results (ANRAKU 1964). Use of radioactive isotopes represents a great step forward and has made comparative studies of feeding relations easier (see, for example, ABraHAM, Hiyama \& Yasuda 1962). Comparing such experiments with the real food web in the sea is like comparing the physiology of reproduction of isolated species with the 
dynamics of complex populations. A dynamic and comparative approach may disclose how selection works and how equilibrium is reached leading to certain types of food web. On this occasion I am interested in such questions as why are there spermwhales at all, if life in the form of a bacterium is so leisurely, rather than in the involved mechanisms of energy transfer and the total amount of energy transferred up to the spermwhales.

The approach proposed here is the following: Ecosystems experience a continuous shift in their structure and function, caused in part by environmental agents, but always through a common process of self organization or succession. As primary food changes in quality along succession, a comparative study of feeding processes and of the organization of the food web in different stages of succession may disclose regularities in the mechanisms of energy transfer, leading perhaps to a few principles of very general applicability. Although the whole picture that emerges seems rather deductive, it can be tested and suggests plenty of new experimental work. Since communities that amount to different stages of succession are found as more or less steady states in separate places, a dynamic approach is possible even without having access to very regular and typical successions.

\section{SUCCESSIONS IN PHYTOPLANKTON}

In previous papers (MARGALEF 1958, 1962) the changes that regularly occur in phytoplankton populations have been discussed. The ever present trends can be reduced to a few ones. Along succession, the average size of cells and the proportion of mobile organisms increase, and production per unit biomass (productivity) or rate of multiplication slows down; there are also regular changes in the chemical composition, exemplified in the complex of plant pigments by the absolute and relative decrease of chlorophyll a. The spectrum of species diversity becomes steeper, and total diversity ordinarily increases in samples of reasonable and ordinary size.

To provide a base for further discussion, a short characterization of the generalized type of phytoplankton succession is provided, arbitrarily divided here in four stages, for the purpose of easier reference.

Stage $I$ is typically represented by blooms in enriched, generally upwelled, water. On the average, the ratio surface: volume of the cells is rather high, about 1 (in $\left.\mu^{2} / \mu^{3}\right)$, the relative concentration of pigments is also high and the pigment index $\mathrm{D}_{430} / \mathrm{D}_{655}$ ordinarily has values between 2.5 and 3.5 . Typical representatives are small flagellates, poorly calcified coccolithophorids, diatoms such as Skeletonema costatum, Thalassiosira subtilis, T. gravida, Chaetoceros socialis, C. radians, C. debilis, Leptocylindrus danicus, Rhizosolenia delicatula, and some Exuviaella and other small dinoflagellates. In coastal waters, Platymonas, Eutreptia, Rhodomonas and pennate diatoms as Asterionella, Thalassionema and Thalassiothrix may be common. Excretion of soluble or mucilaginous materials seems to be important at this stage. The cells of diatoms are often envelopped in mucilage and their appendages, if present, are not very rigid. Cells may divide once a day or more often and reach easily densities of 
100 to 1000 cells per $\mathrm{ml}$; density of populations is limited mostly by diffusion or dispersal of cells around patches of high productivity.

Stage II is characterized chiefly by the development of the bulk of genera of planktonic diatoms, especially Chaetoceros, with cells of medium size and linked in chains with long bristles. The ratio surface : volume is around 0.2 to 0.5 (in $\mu^{2} / \mu^{3}$ ), and much higher if the surface of the appendix of the cell is taken into account. Pigment concentration is lower than in stage $I$, and pigment ratio $D_{430} / D_{655}$ ranges in general between 3 and 4. Coccolithophorids have well developed coccoliths and, besides the dominant diatoms, a considerable proportion of dinoflagellates is present, with species of Prorocentrum, Phalacroma, Dinophysis, Peridinium of small and medium size (P. trochoideum, P. punctulatum, P. brochi) and Ceratium (C. furca, C. fusus, C. tripos). Species diversity is considerable. Population density is around 20 to 100 cells per $\mathrm{ml}$, and turnover time is of the order of a few days.

Stage III, a continuation of the preceding stage, occurs around the places of upwelling or during later periods of the season. It is characterized by the development of diatoms of the genera Bacteriastrum, Coretbron, Nitzschia and, principally, Rhizosolenia with big and cylindrical cells. Dinoflagellates and coccolithophorids increase in number.

Stage IV appears only under poor nutritional conditions or in oceanic situations. In stratified water, after consumption of nutrients in the surface layers, diatoms sediment rapidly and disappear. Only a few species survive, like Hemiaulus baucki, Rhizosolenia calcaravis, and Nitzschia "delicatissima", and the most persistent diatoms are either associated with bluegreen algae, e. g. some Rbizosolenia, or with ciliata acting as agents of suspension, e. g. Chaetoceros. Dominant organisms are motile and, among them, the most conspicuous are dinoflagellates (Ceratium, Dinophysis, Goniaulax, Ornithocercus, Podolampas, Oxytoxum, Pyrophacus) of considerable cell size and, sometimes, toxic. Many coccolithophorids with rater elaborate shells (Rhabdosphaera, Umbilicosphaera, Syracosphaera) are present, and also the bluegreens of the genus Oscillatoria (section Trichodesmium or Skujaella). The ratio surface : volume is, in general, much lower than in previous stages, and there is a higher proportion of passive material in the form of membranes, covers and keels. Thickening of membranes and development of keels is associated with a low rate of cell division. Phytoplankton cells in stage IV of succession divide often only once a week, if one has to trust estimates of primary production, always low, but that can be sub-estimated owing to a possible recycling of nutrients. In any case, there is always a small fraction of the biomass represented by flagellates of small size and, possibly, a more rapid turnover. Population density is usually below 10 cells per ml. Pigment contents of cells is low and pigment ratio $\mathrm{D}_{430} / \mathrm{D}_{663}$ exceeds 4 . As in this stage the proportion of animals containing carotene is high in the total plankton biomass, they further increase an already high pigment ratio. If succession is not interrupted by mixing or upwelling, dinoflagellates and other organisms almost devoid of pigments become increasingly common (Pyrocystis, Histioneis, Ornithocercus). They must be more or less heterotrophic, but their nutrition is not known; they sometimes are associated with bluegreens or with yeasts.

The preceding statements are based mainly on our own work in the Mediterranean 
and Caribbean, but published information of other areas has also been considered, and it seems that the model of succession presented reflects general aspects.

Obviously, the food available to grazing animals is of different quality according to the stage of succession. It is also replaced in different rates. Succession in animal populations has to be linked causally with succession in food availability. A careful study of the food web on this basis of successions may disclose selective forces at work.

The essential changes can be described as the passage from food in form of small particles, covered by rather thin membranes, of high nutritive value and dispersed in turbulent water, into another kind of food concentrated in a smaller number of bigger particles, often mobile, poorer in pigments, with harder covers, sometimes toxic, and distributed in an environment that can offer more clues in form of gradients in physico-chemical properties or waves generated by the activity of organisms.

A function describing how the total phytoplankton biomass is distributed in size classes may be characteristic of the community and important in the study of feeding of phytophagous zooplankton. In the first stages of succession, the biomass (number of cells $X$ average cell mass of the corresponding size class) is a monotonously decreasing function of cell size. In further stages, the function becomes less steep, flattens and eventually shows a maximum in one of the larger size classes. Today it is possible to use electronic dimensional particle counters to obtain rapidly spectra of size distribution of particles. Unfortunately these counters do not differentiate between plankton and detritus. They may be significant in the study of the organization of the ecosystem and of the quality of the food available to animals. In recent cruises (Margalef and coworkers, in press), a particle counter was employed routinely, and the ratio "number of big particles/number of small particles" was found to be significantly correlated with other parameters concerning the organization of the pelagic community, e. g. pigment ratios.

An important feature is the increasing number of mobile organisms along succession stages. Motility is not an asset in turbulent water, but it is an important factor for survival in stabilized water, not so much as a means of avoiding sedimentation but as a way of increasing absorption (CARLSON 1962). It is significant that in the dinoflagellates the flagellum in charge of an apparently senseless spinning takes up more energy than the flagellum pushing up the cell. The combination of the spinning movement and the pronounced asymmetries in body shape must accelerate diffusion very effectively. In any case it must generate waves in the fluid that can serve as clues to the animals in quest of prey, although dinoflagellates seem to be not too palatable.

Detritus and bacteria are important in the transfer of energy, but it is not possible yet to make generalizations. The significance of detritus as food for animals is still controversial. One thing is certain: the appearance of detritus material is different depending on the stage of plankton succession; it ranges from succulent looking detritus in the second stage to a material of a rather hard or fibrous appearance in the later stages; data about chemical composition are badly needed, at least about the $\mathrm{C} / \mathrm{N}$ ratio in the particulate non-living material. In addition to the particulate detritus, there is the huge store of dissolved organic material, the chemical composition and eventual utilization of which may be assumed to differ in accordance with the composition of the plant populations with which it is in equilibrium. 


\section{SUCCESSION OF TYPES OF FEEDING}

Information about feeding of pelagic animals is, at best, patchy, but regularities can be recognized. Most of the information deals with copepods (e. g. Gauld 1951, Marshall \& Orr 1962, Anraku 1963, 1964), important converters of energy in the first trophic level, but other plankton components are also important. Tunicata, for example, exploit intensely almost any dense phytoplankton population, probably even better if the algae are held with mucilage, as is the case in Chaetoceros socialis or Thalassiosira subtilis, and are thus linked to the first stages, at least some of the species. Big size and low metabolism are characteristic for them.

Many copepods are mostly plant feeders (Oithona, Metridia, Acartia, Calanus, Paracalanus, Pseudocalanus), others may be considered omnivorous as they change their food source with age, e. g. Cetropages, Temora, Gaidius, Eucbaeta. Some proportion of detritus material can always be ingested. Finally, Candacia, Tortanus, Anomalocera, Labidocera, Scolecitbrix, Euchaeta and Batbycalanus are carnivorous and predatory copepods. But the most useful classification of animals is according to the way they take up food: microphagous forms, filter feeders or sedimenters feeding in an automatic and rather indiscriminate way (Oithona and some Calanus, Salpa), and macrophagous forms selecting and hunting prey of relatively big size, e. g. Candacia and Anomalocera. In this sense a small jellyfish is a macrophagous animal, and a big baleen whale, a microphagous one.

Zooplankton cycles in the Western Mediterranean (VIVEs 1966) compared to phytoplankton successions in the same waters are consistent with similar information available from other areas. With stages I and II of the phytoplankton succession, filter feeding copepods of small size and short life are associated, such as Oithona. Species of Centropages, Paracalanus and Calanus belong to stage II. At this moment there are plenty of small ciliates, one for every 40 algal cells in the Mediterranean, and such protozoans may be an important intermediate link within the food chain. The macrophagous species of Candacia, Anomalocera, Temora and Oncaea develop in such a way that adult stages are commonly associated with stages III and IV of phytoplankton succession. But they eat in fact little phytoplankton, if any, and are probably supported by the further development of intermediate links of the chain. Conover (1964) makes the assumption that an excess of phytoplankton production stimulates zooplankton reproduction, resulting in a rapid increase of young and small animals that serve as intermediate links in the food chain. Also, ciliates, a surplus of nauplii and other larval forms would serve as energy gates between trophic levels coming apart. Information about utilization as food of the big elements of phytoplankton towards terminal stages of succession is practically lacking.

Some inconsistencies may be found in the presence of macrophagous bathypelagic copepods in the first stage of succession. They come with upwelled deep water or by migration after the disappearance of the thermocline and are good indicators of the fertilization process going on, but their populations are never great. This is a good example of how vertical movements, the importance of which has been emphasized by HARDY, can reorganize ecosystems and create very complex situations. It can be suspected that cycles and behaviour of animals has evolved in relation to the ordinary 
way plankton successions proceed and local hydrographic conditions develop. In general, macrophagous animals have a longer life, and the adults appear later (after the microphagous forms) in correspondence with a shift in the average size of the available food.

Animals are an important factor in controlling the speed and direction of phytoplankton successions. A strong increase in filter feeders results in a selective advantage for organisms of big size, linked in chains and possessing long bristles, pushing ordinary succession forward in the first stage, although Mulin (1963) finds the conflicting evidence that Calanus gets easier hold of big chain-forming cells. In later stages of succession, development of macrophagous animals mobilizes nutrients that are excreted into the water and stimulate the development of algae of small size, which remain out of their reach, reversing succession in a certain way but, in fact, regulating its speed. In general, speed of phytoplankton succession - or of any succession - is slowed down by any exploitation, loss of cells through sinking, diffusion or grazing; in the absence or limitation of such losses, succession in small bays or in laboratory cultures proceeds rapidly. Animals not only operate by increasing energy fluxes through the plants and thus slowing down the process of organization at the plant level, but also by exerting specific selection pressures on certain kinds of cells. Phytoplankton and grazers are linked in a feed-back circuit that not only checks mutually the population densities but regulates as well certain trends in the overall adaptive characteristics of the populations.

\section{A GENERAL EXPRESSION FOR ENERGY INPUT AND OUTPUT IN PELAGIC ANIMALS}

It is possible to offer different food items to a species reared in the laboratory, find out which of them are compatible with its feeding mechanism, measure the degree of their utilization and somehow estimate the food conditions required for the maintenance of a population of such animal. Going back to nature, it is necessary to add another dimension: Given an assemblage of many kinds of food and many animals that can use these foods, one must try to see if it can be understood how things organize themselves and create forces operative, both in terms of ecological succession and evolution of species.

A very general balance sheet that fits almost any heterotroph organisms can be drawn, assuming a steady state as a first approximation. Energy input or flow of energy associated with the flow of organic matter per unit time $\left(F_{c}\right.$, of dimensions $\mathrm{ML}^{2} \mathrm{~T}^{-3}$ ) can be expressed by the following sum of terms:

$$
\mathrm{F}_{\mathrm{c}}=\mathrm{L} \Sigma \mathrm{D}_{\mathrm{i}} \mathrm{N}_{\mathrm{i}} \mathrm{B}_{\mathrm{i}}+\mathrm{E} \Sigma \mathrm{N}_{\mathrm{i}} \mathrm{B}_{\mathrm{i}}+\mathrm{V} \underset{\mathrm{h}-\mathrm{k}}{\sqrt{\sum_{\mathrm{i}}} \frac{\mathrm{N}_{\mathrm{i}}}{\sum_{h-\mathrm{k}} \mathrm{N}_{\mathrm{i}} \mathrm{B}_{\mathrm{i}}}}
$$

The meaning of the symbols is as follows: $\mathrm{L}$, some linear dimension of the feeder c; $B_{i}$, energy associated to every individual of food species $i ; N_{i}$, density of population 
of food species $i ; \sum_{h-k} N_{i} B_{i}$, total energy per unit space associated with the mixed population of food species, in this case taking only the food species which size ranges from $\mathrm{h}$ to $\mathrm{k}$; $\mathrm{E}$, volume swept clear or filtered in unit time, can be considered also as a product of speed V by a "section" dependent of the geometrical section of feeder ( $\left.\mathrm{L}^{2}\right)$ and of its form of movement and mechanism of filtration; $D_{i}$, diffusion coefficient of species or compound $i ; D_{c}$, diffusion coefficient of the movement of feeder or predator $c$, related to the average velocity of its individuals; V, velocity of feeder or 3

predator $\mathrm{c} ; 1 / \sqrt{\mathrm{h}-\mathrm{k}} \mathrm{N}_{\mathrm{i}}$, average distance between individuals that fall within ranges of size $h$ to $k$.

Alternative ways to write the second term may be: $L_{\mathrm{c}} \Sigma \mathrm{N}_{\mathrm{i}} \mathrm{B}_{\mathrm{i}}$, in which case (1) and (2) may be combined as $\mathrm{L}\left(\mathrm{D}_{\mathrm{i}}+\mathrm{D}_{\mathrm{c}}\right) \Sigma \mathrm{N}_{\mathrm{i}} \mathrm{B}_{\mathrm{i}}$ (see CARLSon 1962), and $\mathrm{VL}^{2} \sum \mathrm{N}_{\mathrm{i}} \mathrm{B}_{\mathrm{i}}$. The third term may be written also as $\mathrm{V}\left(\sum_{\mathrm{h}-\mathrm{k}} \mathrm{N}_{\mathrm{i}}\right)^{-2 / s} \sum_{\mathrm{h}-\mathrm{k}} \mathrm{N}_{\mathrm{i}} \mathrm{B}_{\mathrm{i}}$; this expression assumes that the predator goes straight from one prey to the next one and loses no time securing and swallowing it; such assumptions are obviously not true; in fact such term must have a stochastic form, more or less like the one proposed by OLson (1964). For the purpose of an elementary discussion of the problem, the suggested general expression probably is not too distorted, if we suppose that every term is multiplied by some coefficient expressing efficiency.

This input has to be balanced against an output, also with many terms:

$$
\mathrm{F}_{\mathrm{c}}=\mathrm{AL}^{2}+\mathrm{BLV}+\mathrm{CV^{2 }}+\mathrm{DMV} \mathrm{V}^{2}+\mathrm{G} \mathrm{Z}
$$

in which $Z$ stands for predators on species c, and $A, B, C, D, G$ are appropriate coefficients, concerning metabolism, resistance, and so on. Term (4) expresses respiration, proportional to the surface of organisms, and the meaning of term (8) is obvious. The terms (5), (6) and (7) express energy used in getting hold of food. For low Reynolds numbers, such energy is rather proportional to the squared speed; for high Reynolds numbers, inertial mass is also important (M). Reynolds numbers is $L V \varrho / \mu$ wehre $\varrho$ is density and $\mu$ viscosity of the fluid. Obviously its value is higher in macrophagous hunters than in microphagous filter feeders, and in these higher than in swimming unicellulars. It is interesting to plot values of $\mathrm{V}$ and $\mathrm{L}$ for many species of plankton, in the way Cushing (1959, Fig. 2) did. Available data show some discontinuity, suggesting that certain values in Reynolds numbers act as thresholds in the divergent evolution of species, with the result that species in different trophic levels are often also hydrodynamically different. But a word of caution is necessary here, since the supposed discontinuities may be artifacts or reflect discontinuities in the study of plankton (use of nets, neglect of ciliates, etc.) with the consequence that the information available is not representative. Term (5) concerns the renewal of water and passage of organisms along the surface on which capture is feasible, and concerns filter feeders. 


\section{TREND IN FOOD WEB ORGANIZATION}

The proposed general formulation may prove accurate or not; but in any case, others, more perfect and based on analogous reasoning, will be appropriate. The particular form of the selected expression is immaterial to the discussion of the general model. Ours has been suggested by a stimulating paper by CARLSON (1962), in which he discussed the advantages of motility in planktonic organisms. Given a set of conditions, motility is advantageous, and there must be an optimal speed that can be estimated: such prediction is confirmed by the substitution of diatoms by dinoflagellates as the most bulky components of phytoplankton, along succession. Using a similar reasoning, a trend in the substitution of species, according to their feeding type, can be predicted, and such a trend is realized either in succession or in evolution.

For the purpose of discussion, consideration can be restricted to the terms (2) and (3) of the input, weighed against most of the terms of the output; in this connection the importance of Reynolds numbers has to be remembered.

A microphagous animal obtains its input according to term (2) [and, of course, (1)]. There is always a limitation in the range of the size of utilized food. Suppose there is a copepod capable of filtering 5 to $100 \mathrm{ml}$ every day and having daily energetic needs amounting to 15 to $25 \%$ of its own body weight. It can subsist in an environment rich in suspended organisms of small size, e. g., in stage I of the phytoplankton succession. The upper limit of utilization may coincide with cells more than $50 \mu$ in diameter (Coscinodiscus, Halosphaera, etc.) or cells associated in chains with long bristles. The lower size limit in usable seston is defined by the special construction of the food collecting mechanisms - in the copepods, ordinarily by the distance between the spines or bristles in the buccal appendages (ANRAKU \& OMORI 1963). In a general way, extremely small sized food (down to molecular size) can be utilized only at very high concentrations, the absolute limit being set when the energy that such food can give is less than the energy necessary to concentrate it.

If a macrophagous animal explores the water at the same speed as a microphagous one, but ingests only selected (biggest) prey, it would, in general, be at a disadvantage because the total amount of ingested food would be only a fraction of what a filter feeder could obtain, and big prey organisms are sparsely distributed. Real success in macrophagous life requires a different behaviour. Animals should move rapidly, following the straightest path between successive encounters and catches; the term (3) has to be applied, including in the sums only the individuals of species that merit attention from the predator. Certainly, the path leading from prey to prey will never be so straight as desirable, and the average number of prey that will in probability be found and caught per unit time is a more complicated function than previously assumed. In it, the radius of perception of a prey by the predator, visual or otherwise, should enter. Animals have to follow some clues that direct encounters to big and valuable items and save time in between. CUSHING (1959) accepts that calanoids can sense the presence of diatoms by means of their antennules, and the algae are then seized. Since in later stages of succession, moving organisms of large sizes are more frequent, it would be easier to detect them at a distance. This is another neglected chapter of plankton 
ecology. At this stage, efficiency of a macrophagous animal depends on factors that are not easily quantifiable but can be related essentially to a more complex nervous system and a more predictable environment in which the task of detection is easier. Of course such predictability depends on stability or stratification of water and in part on information accumulated in the species.

The following may be concluded. Given reasonable assumptions as to the energy needed for movement and so on, it can be predicted that the advantage goes either to the microphagous or to the macrophagous, according to the function that describes the distribution of the mass of the different items of available food in terms of size classes. It can be predicted also that evolutionary divergence between microphagy and macrophagy must be rapid, and once is entered the path of macrophagy, the fate is decided and evolution should proceed towards increased prey size.

In the first stage of phytoplankton succession, most of the available food is concentrated in the smallest size classes, and microphagous organisms can subsist easily. The function describing distribution of total food in size classes is rapidly decreasing. It would be interesting to define a limit in such a function, above which the distribution of primary food in size classes stimulates the development of macrophagy, even in plant feeders. Here macrophagy and selective feeding are employed indistinctly. Such boundary conditions can be found easily. The values of

$$
\left(\sum \mathrm{N}_{\mathrm{i}}\right)^{-2 / 3} \sum_{\mathrm{h}-\mathrm{k}} \mathrm{N}_{\mathbf{i}} \mathrm{B}_{\mathrm{i}}
$$

are computed successively for a series of ranges of $h-k$, starting with the whole mixed population in the complete range of sizes, and then taking away always the smallest size class in successive steps, up to a last term in which only the biggest organisms are taken into account. Now, if the series of numbers thus obtained increases, it pays to follow the path of macrophagy. It involves of course some gambling; it is like leaving a modest job for big business. On the other side, there is the sheet with the expense of energy, and increasing speed represents a supplementary output. But the coefficients $A$ to $G$ in the second member of the equation show a trend to drop along the path of macrophagy; in relation to the larger size of the predators, longer life and freedom of being preyed upon. Here is a strong drive for succession, and since ecological succession, representing a slow and recurring phenomenon, is the matrix for many so called "orthogenetic" evolutionary ways, it can be easily understood why we so often find the passage from microphagy to macrophagy in phylogenetic lineages.

It pays to specialize in larger prey and this can be achieved only by restricting the choice and fighting against the limitations imposed by turbulence of water or absence of clues in the exploratory behaviour. Species pursuing large items of food diverge easily in their preferences, and the impact of this process can be recognized in the evolution of sympatric pelagic predators (Cephalopoda, Tunnidae).

Filter feeders in advanced stages of succession remain of course if food of small size is still present, as always is, although in a smaller proportion than in the firsts stages. But the low concentration of food imposes an increase of efficiency or a lower turnover. There must also be an evolution in such filter feeders. Sympatric species in a group may show food segregation, as happens with fresh-water species of Arcto- 
diaptomus. In such case, they are linked to differences in size, or, better, in the respective Reynolds numbers.

Formation of swarms is like maintaining constant the product $\mathrm{N}_{i} \mathrm{~B}_{\mathrm{i}}$ but increasing the distance between feeding places, that is, reducing $N_{i}$ and increasing $B_{i}$ accordingly. In principle, this is good for the predator and bad for the prey. Against such a bargain for the predator, however, difficulties exist of locating prey at a larger distance and the possible food saturation of the predator (OLson 1964), and in turbulent water with few long distance clues, the advantage in the formation of swarms is certainly on the side of the prey. It conforms with the general trend to concentrate organic matter in bigger and bigger centers.

Nothing mysterious clouds the trend towards macrophagy, which is well realized in environments where ecological succession has proceeded to an advanced stage. At such a stage there has been occasion to add new trophic levels and thus complicate the food web. In coastal or upwelled waters, where succession is found in the initial stages, there are plenty of filter feeders, and food chains are rather short, like those leading to engraulidae or clupeidae, or even to small scombridae, or to baleen whales. In the true oceanic areas, in more advanced or mature stages of succession, long, more complex, and presumably more efficient food chains are found, with a predominance of macrophagous forms, leading to the giant squids and sperm whales. Organization of the ecosystem, as reflected in the complexity of food chains, is not proportional to the intensity of primary production; in contrast, it is based primarily on stability, and stability in the sea is not compatible with high productivity. In any case, it seems to me that the basic mechanisms involved in such a display of different ways of feeding can be traced down to what happens when the spectrum of distribution of phytoplankton is size classes changes as a consequence of, primarly, the consumption of nutrients along phytoplankton successions.

\section{SUMMARY}

1. The study of grazing along ecological successions helps in understanding how the mechanisms of transfer of energy evolve and provides a measure of its effectiveness in the different situations. Phytoplankton populations show regular changes along succession. Average size of cells and relative abundance of mobile organisms increase, and productivity or rate of multiplication slows down; there are also changes in the chemical composition, exemplified in the plant pigments by an absolute and relative decrease of chlorophyll a.

2. Along a succession, animals are offered different kinds of food, and the resulting selection produces a shift in the composition of zooplankton populations. The speed at which phytoplankton succession proceeds is a very important factor, and grazing may be effective in the regulation of such speed. In a general way, along usual successions, food in the form of small particles, richly suspended in a more or less turbulent environment, is replaced by scarcer food concentrated in bigger units and dispersed in a more organized (stratified) environment.

3. Indiscriminate filter feeders are at an advantage in the first stages of succession, 
but it can be shown that, given the usual properties of food organisms in later stages, it pays to adopt a more selective and hunting behaviour and to concentrate more and more on bigger prey. The effectiveness of such adaptation depends on the distribution of food in size classes and also on its mobility or other clues that prey organisms can offer, and, in general, on the predictability of their distribution. Divergence between microphagous passive filterers and macrophagous hunters must be rapid. Distribution of populations of copepods along time and in relation with phytoplankton distribution sustain such views.

4. In general, in later stages of succession, total transfer of energy may be lower, buts its efficiency seems to be regularly improved. Similar considerations could be extended to the discussion of energy transfer between other, superior, trophic levels.

\section{LITERATURE CITED}

Abraham, D., Hiyama, Y. \& Yasuda, F., 1962. Quantitative relation between marine and freshwater preys and predators determined by 32-P. Bull. Jap. Soc. sci. ent. Fish. 28, 1092-1098.

Anraku, M., 1963. Feeding habits of planktonic copepods (Review). Inf. Bull. Planktol. Japan 9, 10-35.

- 1964. Some technical problems encountered in quantitative studies of grazing and predation by marine planktonic copepods. J. oceanogr. Soc. Japan 20, 19-29.

- \& Omori, M., 1963. Preliminary survey of the relationship between the feeding habit and the structure of the mouth-parts of marine copepods. Limnol. Oceanogr. 8, 116-126.

Carlson, F. D., 1962. A theory of the survival value of motility. In: Spermatozoon motility. Ed. by D. W. Bishop. (A.A.A.S. Symp. 72, 137-146.)

Conover, R. J., 1964. Food relations and nutrition of zooplankton. In: Experimental marine ecology. Proc. of a symposium held at the Univ. of Rhode Isl., Oct. 18-19, 1963. (Occ. Publs Narragansett mar. Lab. 2, 81-91.)

Cushing, D. H., 1959. On the nature of production in the sea. Fishery Invest., Lond. (Ser. 2) $22(6), 1-40$.

Gauld, D. T., 1951. The grazing rate of planktonic copepods. J. mar. biol. Ass. U. K. 29, 695-706.

Hardy, A. C., 1953. Essays in marine biology. Oliver \& Boyd, Edinburgh \& London. 101-121.

Margalef, R., 1958. Temporal succession and spatial heterogeneity in phytoplankton. In: Perspectives in marine biology. Ed. by A. A. Buzzati-Traverso. Univ. Calif. pr. Berkeley, 323-349.

- 1962. Succession in marine populations. Advg Frontiers Pl. Sci., New Delbi 2, 137-188.

Marshall, S. M. \& OrR, A. P., 1962. Food and feedıng in copepods. Rapp. P.-v. Réun. Comm. int. Explor. scient. Mer Méditerr. 153, 92-98.

Mullin, M. M., 1963. Some factors affecting the feeding of marine copepods of the genus Calanus. Limnol. Oceanogr. 8, 239-250.

Olson, F. C. W., 1964. The survival value of fish schooling. J. Cons, perm. int. Explor. Mer 29, 115-116.

VIves, F., 1966. Zooplancton nerítico de las aguas de Castellón (Mediterráneo occidental). Investigación Pesq. 30, 49-166. 


\section{Discussion following the paper by MARGALEF}

Bonden: I was very interested to hear of your work on fine particle size and feeding. This summer I have been using a Coulter Counter to count very fine particles in sand. The results are in a preliminary stage, but there seems to be a correlation between very fine particles and at least two or three species of the interstitial fauna.

Margalef: Were the particles on the sand surface layer or in the sand?

BOADEN: The particles were from within the sand. We first removed the larger sand and substrate particles and then measured the small particles with the Counter. 